\title{
Anatomical Studies on the Androecia of Some Members of the Guttiferae-Moronoboideae*
}

\author{
by Shoichi KaWANo**
}

\section{Received January 11, 1965}

The Moronoboideae, a small subfamily of the Guttiferae, is represented by seven genera, distributed mainly in the Neotropics, tropical Africa and New Caledonia: Platonia (one species in Guiana and Amazonas), Moronobea (7 species in Guiana and Amazonas), Pentadesma (one species in West Africa), Lorostemon (three species in Amazonas to Brazil), Thysanostemon (two species in Guiana), Montrouziera (three species in New Caledonia), and Symphonia (16 species in Madagascar and one species from tropical Africa to West Indies, Central and South Tropical America) (cf. Engler'), Hutchinson $^{21}$, Maguire ${ }^{3)}$, Perrier ${ }^{4)}$ ). This subfamily has been one of the least known members of the Guttiferae, but a few contributions on its taxonomy were recently made by Maguire ${ }^{3)}$ and Kawano ${ }^{5)}$. One of the most characteristic gross morphological features of the Moronoboideae*** is the so-called fasciculate androecium, where the stamens are aggregated in five discrete phalanges, each with a long linear anther fused abaxially to the connective tissue throughout their length. On the basis of this characteristic fasciculate androecium, these seven genera are grouped together taxonomically as a subfamily of the Guttiferae, namely the Moronoboideae.

In a previous work, the present author described in detail the gross morphological characteristics of androecia of representative members of all seven genera belonging to the Moronoboideae. The systematic position and phylogenetic relationships of these genera were also discussed together with evidence from pollen morphology. It was pointed out on the basis of the evidence gathered that there are two clear evolutionary trends in the Moronoboideae. One evolutionary group is represented by Pentadesma, Platonia and Lorostemon, in all of which the stamen fascicles have numerous long slender stamens in each phalange, arranged more or less vertically and fused only at the base. The second group includes Moronobea, Montrouziera and Thysanostemon, in which each phalange of stamen fascicles bears only two to eleven stamens and the stamens are fused up to onehalf of their height, forming massive connective tissue. The most extreme example of fusing is seen in Symphonia, in which the five stamen fascicles, each bearing three or four anthers, are completely fused together into a flat tube.

As a continuation of earlier studies (1. c.), further critical observations are presented here on the anatomical structure of the androecia of four genera, Montrouziera, Moronobea, Symphonia and Thysanostemon, belonging to the Moronoboideae, and in addition problems relating to the origin of the stamens of angiosperms are discussed.

* Contributions from New York Botanical Garden, New York, U. S. A.

** Department of Botany, Faculty of Science, University of Tokyo, Tokyo, Japan.

*** In the recent treatment by Hutchinson ${ }^{2)}$, the Guttiferae was divided into two families, Hypericaceae and Clusiaceae, the Moronoboideae being assigned to the latter. In the present paper, however, the Guttiferae sensu lato is adopted. 


\section{Material and Methods}

The flowers of Moronobea, Symphonia and Thysanostemon, fixed in FAA in the field, and dried herbarium specimens of two species of Montrouziera were used as materials for study. Flowers of Moronobea, Symphonia and Thysanostemon were cut into small pieces, dehydrated, and embedded into paraffin by the usual technique. Sections were cut at $15 \mu$ and stained with safranin and methylgreen. Dry materials of Montrouziera were soaked in $0.2 \% \mathrm{NaOH}$ solution overnight, rinsed in running
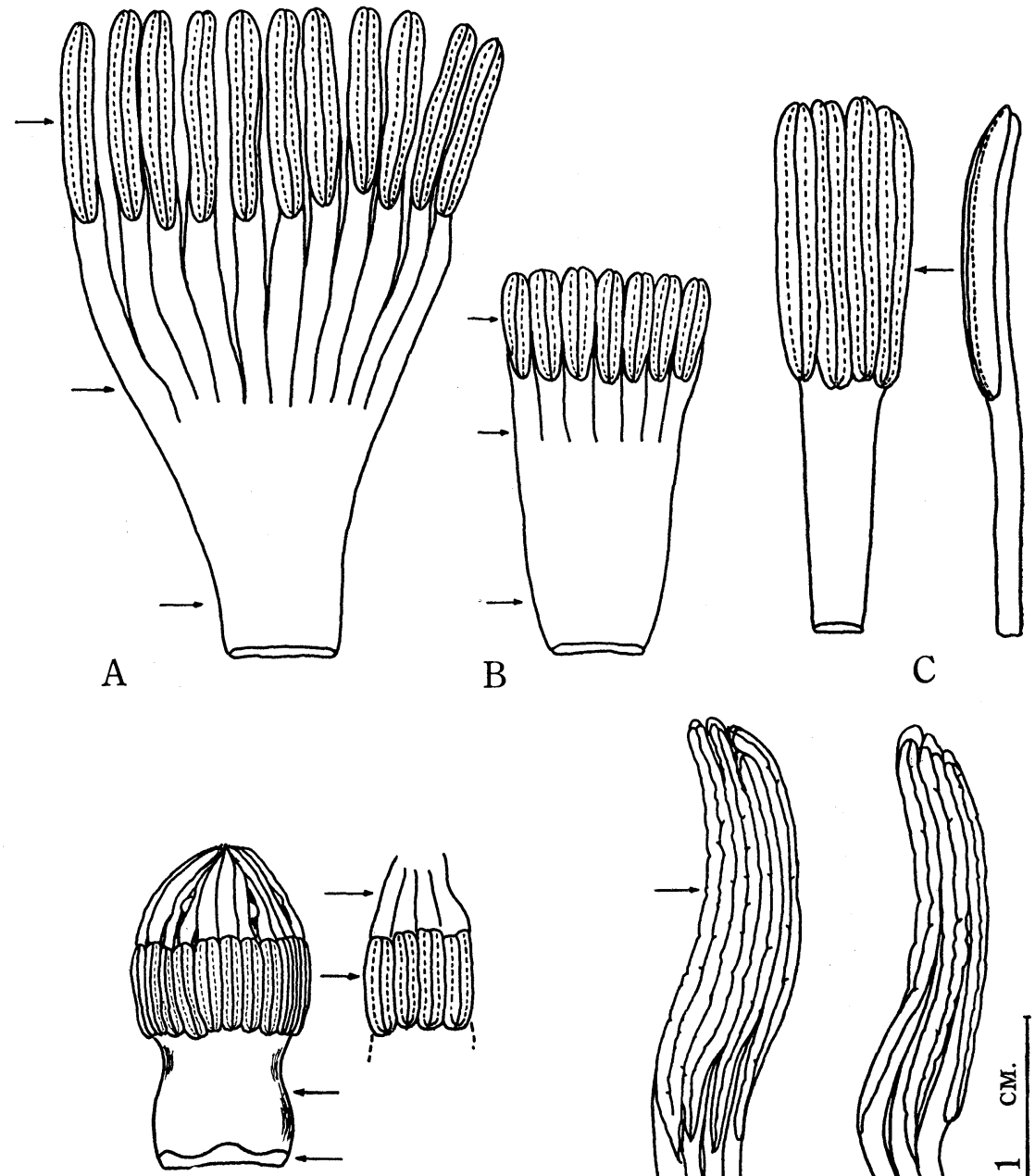

$\mathrm{D}$
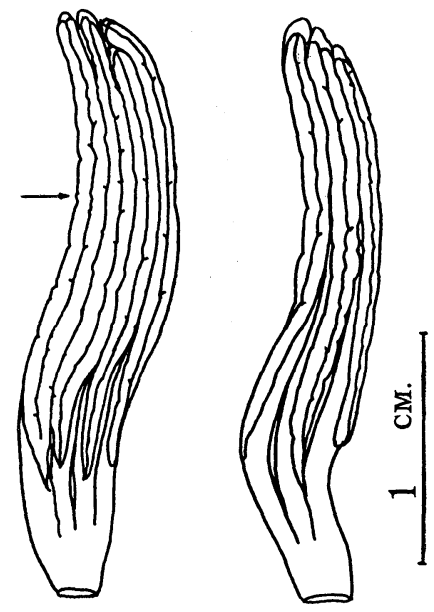

$\mathrm{E}$

Fig. 1. Stamen fascicles of the Moronoboideae.

A: Montrouziera cauliflora; B: Montrouziera sphaeroidea; C: Thysanostemon pakaraimae; D: Symphonia globulifera; E: Moronobea ptaritepuiana ssp. neblinae.

Arrows indicate the positions sectioned and shown in the figures 2, 3, and 4. 
water for $10 \mathrm{~min}$., run through the alcohol series in the usual manner, and embedded in paraffin. Sections were also cut at $15 \mu$ and were stained with safranin and methylgreen. All voucher specimens are preserved in NY.

\section{Observations}

\section{(1) Montrouziera sphaeroidea Pancer (Figs. 1-B; 2-A $\mathrm{H}$; 3-F)}

Stamens are 15-20 mm long at maturity, aggregated in 5 discrete phalanges, 7 per phalange, uniseriate, and lower half of the filaments connate; the sporangia are linear and abaxial, ca. $5 \mathrm{~mm}$ long, protuberant in pairs (Fig. 1-B); the massive connective tissue has ca. 20 latex glands at the periphery (Fig. 3-F). At about the point where the gaps to the sepal traces close, the stele becomes somewhat star-shaped by the outward development of V-shaped masses of tissue. The V-shaped masses then become U-shaped (Fig. 1-B, Fig. 2-A and B), and the gaps close as the strands move into the cortex of the receptacle. The ends of these groups of tissue now move toward the center, and the five dissected horseshoe-shaped masses of tissue lie outside of a central ring which forms the vascular supply for the gynoecium (Fig. 2-C). Each horseshoe-shaped mass of tissue then forms the vascular supply for the petals and stamen fascicles. One mass of tissue can be traced directly to the base of a petal, and the remaining mass of bundles form the supply for a single fascicle. Each of these stamen fascicle traces then gradually becomes laterally elongated (Fig. 2-D and E) and breaks up into seven small dissected siphonosteles (Fig. 2-G), each of which supplies a stamen and spreads open in a U-shape at the outer or closed end. Small traces can often be followed outward from the abaxial end of the bundles.

\section{(2) Montrouziera cauliflora $\mathrm{Pl}$. et Triana (Figs. 1-A, 3-A $\sim$ E)}

Stamens are ca. $30 \mathrm{~mm}$ long at maturity, aggregated in 5 discrete phalanges, 11 per phalange, uniseriate, and lower $1 / 3$ of the filaments connate; the sporangia are linear, abaxial, ca. $10 \mathrm{~mm}$ long, protuberant in pairs (Fig. 1-A); the massive connective tissue has ca. 20 latex glands at the periphery (Fig. 3-E). The general pattern of the vascular system in the stamens is similar to that of Montrouziera sphaeroidea. A noteworthy difference is found at the level where the stamen fascicle traces, forming the vascular supplies for each stamen, break up into eleven small dissected siphonosteles. The behaviour of bundles in the stamen tissue is nearly identical with that observed in $M$. sphaeroidea.

\section{(3) Moronobea (Figs. 1-E, 3-H and I, 5-A $~ C$ )}

Two species, $M$. riparia and $M$. ptaritepuiana subsp. neblinae, were examined (Fig. 1-E). Stamens are aggregated in 5 discrete phalanges, 2-6 per phalange, uniseriate, often spirally entwined about the ovary ( $M$. riparia); the filaments are basally connate; the sporangia are on the abaxial side, protuberant in pairs, $20 \mathrm{~mm}$ long in $M$. ptaritepuiana subsp. neblinae, and $30 \mathrm{~mm}$ long in $M$. riparia; the massive connective tissue terete in cross section, has 13-15 latex glands at the periphery (Fig. $3-\mathrm{H}$ and I). The general pattern of the vascular system in the stamen fascicle of the Moronobea species is very similar to that observed in Montrouziera, suggesting a close affinity. However, amphicribral bundles are formed where the five siphonosteles, each originating from the receptacular stele, form vascular supply for each stamen. Furthermore, these bundles can be traced in the connective tissue to the 
upper portions of each stamen, where the bundles, especially at the lower portion of the anther, become irregularly arranged, in contrast to those of Montrouziera and Thysanostemon (cf. Figs. 2-G and H, 3-E, F, G, H and I).

(4) Thysanostemon pakaraimae Maguire (Figs. 1-C, 3-G, 4-E $\sim$ G, 5-D and E)

Stamens are $20-25 \mathrm{~mm}$ long at maturity, aggregated in 5 discrete phalanges, $4-5$ per phalange, uniseriate, and lower half of the connective tissue connate; the sporangia are linear, ca. $13 \mathrm{~mm}$ long, abaxial in the upper half, protuberant in pairs, the massive connective tissue terete in cross section (Fig. 1-C; Fig. 3-G). The general pattern and behaviour of the petal-stamen fascicle traces are similar to those of Montrouziera and Moronobea. As observed in the species belonging to the three genera described above,

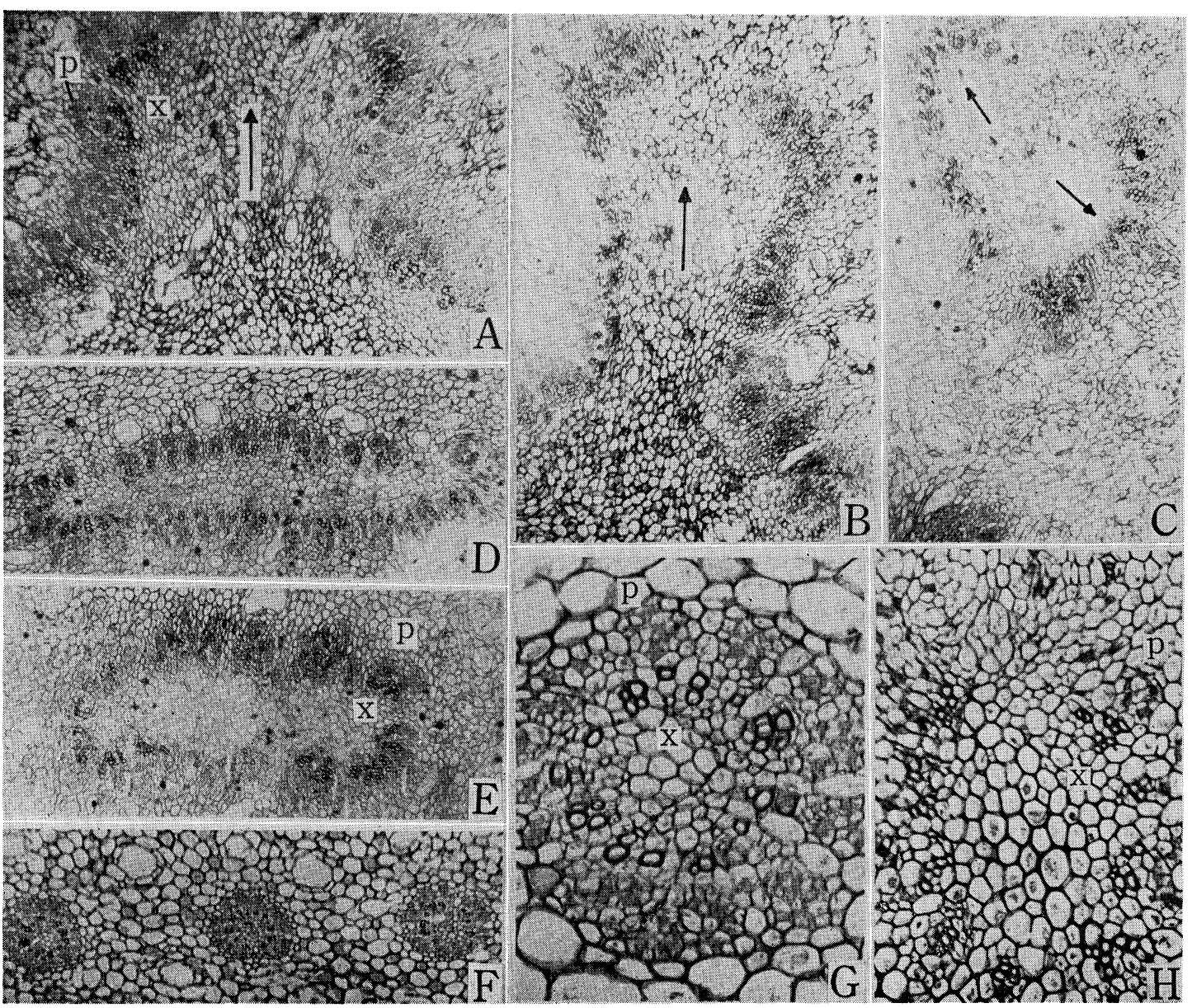

Fig. 2. A-H: Montrouziera sphaeroidea.

$A$ and B: Cross section at the level of organization of the petal-stamen fascicle supply. Masses of tissue becoming U-shaped by the outward movement; C, D. and E: Cross section of the stamen fascicle supply. The stamen fascicle trace becomes laterally elongated at this level; $\quad F$ and G: Cross section of the stamen trace. Small concentric bundles supplying each stamen are seen; $H$ : Cross section of the stamen trace. Bundles spread open at the base of the anther, 


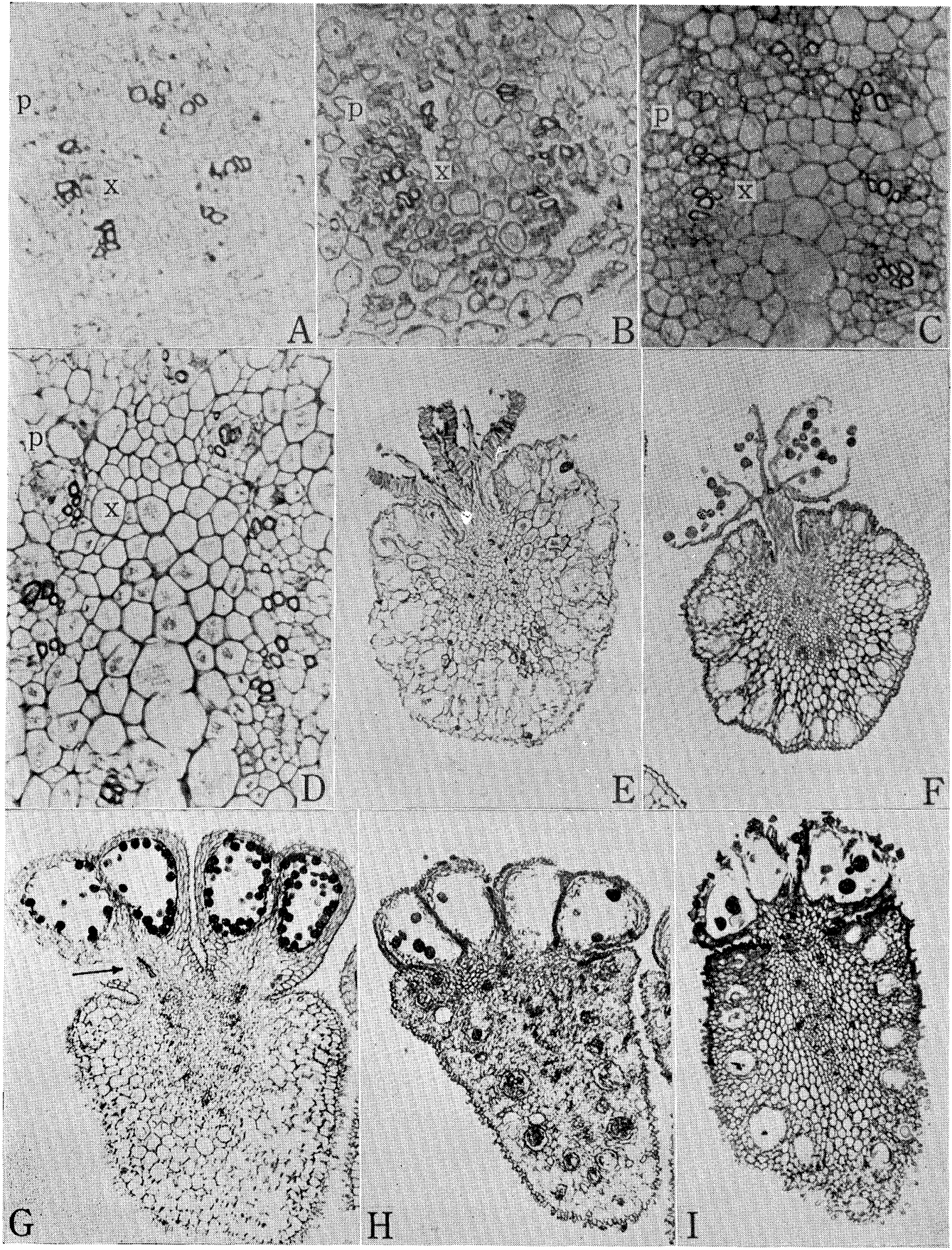

Fig. 3. A-D: Montrouziera cauliflora. A-D: Cross section of the stamen trace, illustrating the gradual spreading of bundles; E: Montrouziera cauliflora. Cross section of the anther; F: Montrouziera sphaeroidea. Cross section of the anther; G: Thysanostemon pakaraimae. Cross section of the anther; H: Moronobea ptaritepuiana ssp. neblinae. Cross section of the anther; I : Moronobea riparia. Cross section of the anther. Note the presence of numerous cavities at the periphery in E, F, H \& I. 
the U-shaped masses of tissue are formed by outward movement, and then five large dissected siphonosteles that are formed constitute the petal-stamen fascicle vascular supplies (Fig. 4-E). Then, the petal vascular supply is formed (Fig. 4-E, cf. arrow), and the remaining masses of tissue form the supply to a single fascicle. Each stamen fascicle supply then becomes subdivided into two groups as shown in Fig. 4-G, and

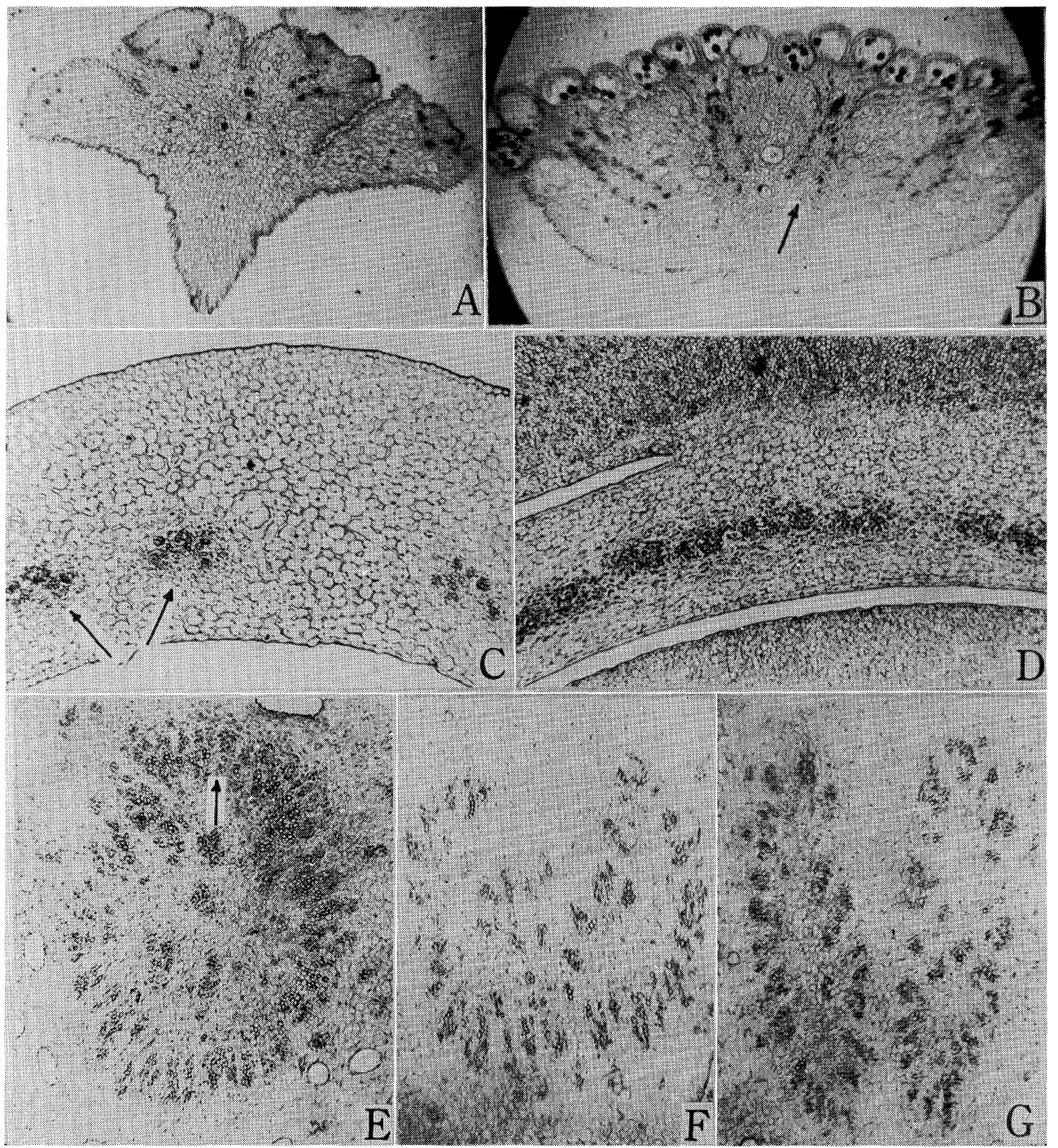

Fig. 4. A-D: Symphonia globulifera.

A: Cross section of the apical portion of the fascicle. Note the absence of bundles; B: Cross section of the fascicle thowing the double nature of the vascular supply to nach stamen (cf. arrow); C: Cross section of the middle portion of the staminal tube; D: 'Cross section of the flower at the level of separation of the petal; E-G: Thysanostemon pakaraimae. E: Cross section of the petal-stamen fascicle supply. Note the emergence of the petal supply (cf. arrow); F and G: Cross section of the stamen fascicle trace just below the four stamen supplies diverge, 
subsequently break up into four or five small siphonosteles, each of which supplies a stamen. Small traces are often seen to move outward from the abaxial end of the bundles, diverging either to the right or to the left (Fig. 3-G, cf. arrow), that is, to one pair of thecae or to the other.

(5) Symphonia globulifera L. f. (Figs. 1-D, 4-A D)

Stamens are $8-16 \mathrm{~mm}$ long at maturity, aggregated in 5 discrete phalanges, the filaments connate throughout forming a flat tube (Fig. $4-C$ and $D$ ); each phalange is free, with four anthers (Fig. 1-D); the sporangia are abaxial, ca. $5 \mathrm{~mm}$ long, protuberant; the massive connective tissue is completely fused on both the abaxial and adaxial sides; the apical portion of the phalanges is fan-shaped in cross section, its adaxial side completely fused (Fig. 4-A); intercellular cavities are numerous but somewhat irregularly scattered in the connective tissue (Fig. 4-B). The pattern of the siphonostelar formation is similar to that seen in the species of Montrouziera, Moronobea and Thysanostemon. Five dissected siphonosteles are formed by the outward movement of tissue masses. These steles constitute the supply to the petal-stamen fascicles, and immediately after breaking up to form the vascular supply to the petals,

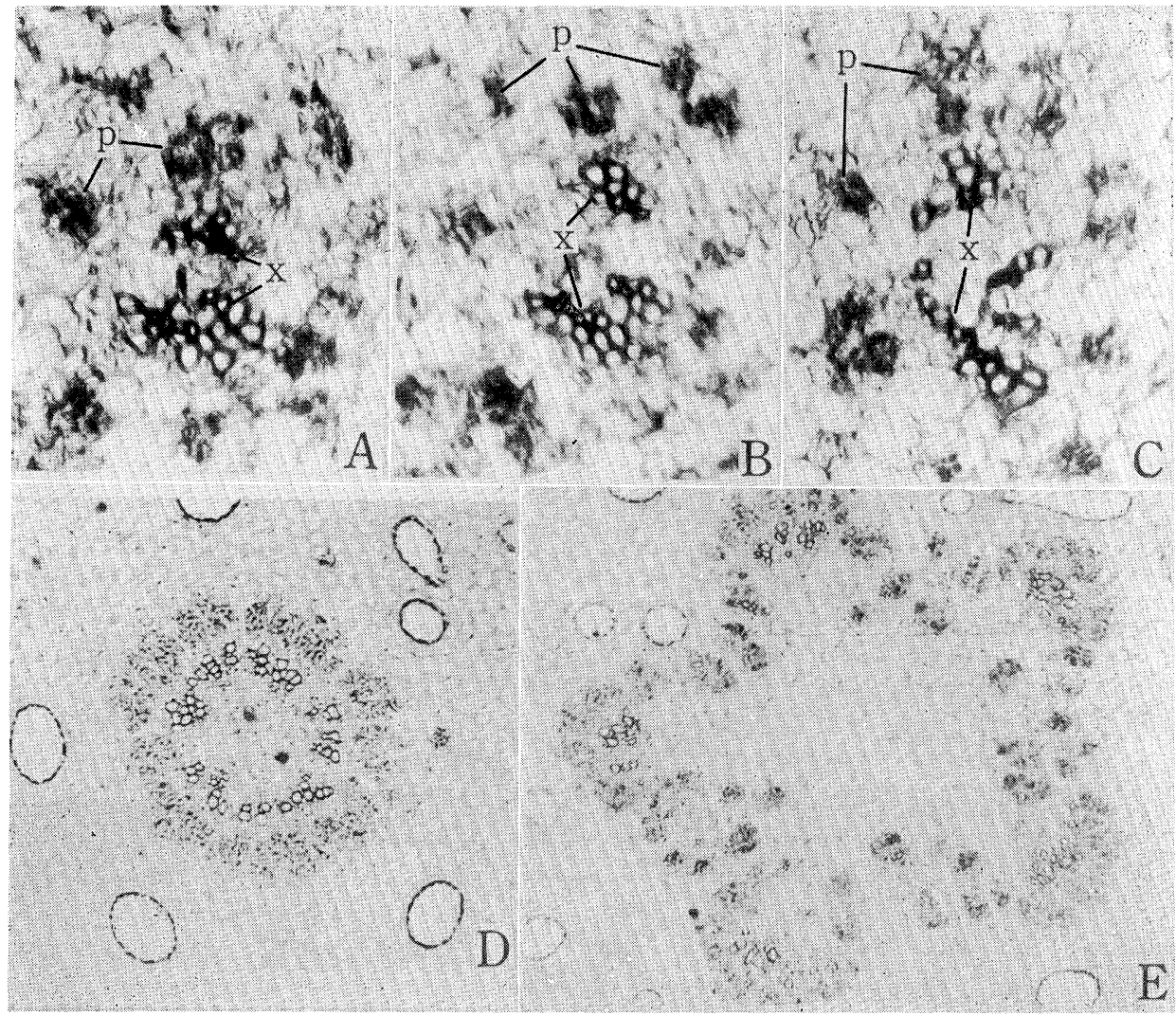

Fig. 5. A-C: Moronobea ptaritepuiana ssp. neblinae. Cross section of the stamen supply. Gradual spreading of the amphicribral concentric bundles is seen in A, B, and C; D-E: Thysanostemon pakaraimae. Cross section of the gynoecium supply. Outward movement of bundles is seen in $\mathrm{E}$. 
two inner bundles form the supply to a single fascicle, each of which shortly forms three or four bundles by the dichotomy of one or both of the bundles (Fig. 4-C, cf. arrow). Numerous vestigial bundles then split off from each of the fascicle traces, Numerous vestigial bundles then split off from each of the fascicle traces, and at about the level at which the stamen tube separates into the constituent fascicles, the paired bundles divide tangentially. The mass of vascular tissue supplying each stamen now forms two rows of irregularly arranged bundles (Fig. 4-B, cf. arrow). No bundles are found in extensions of the fascicles above the anthers (Fig. 4-A).

\section{Discussion}

The fasciculate androecia of the Guttiferae-Moronoboideae just described are among the most extraordinary types found in the angiosperms, with very characteristic vascular system, i. e. the vascular supply to the stamens arising as the result of the division of a single bundle that originates directly from the receptacular stele (called "stamen fascicle trace" by Wilson $\left.{ }^{6}\right)$. As a matter of fact, some earlier morphologists called attention to this specific type of androecium in the angiosperms, called the fasciculate androecium $\left.{ }^{6-11}\right)$ of these authors, Wilson particularly made extensive anatomical surveys (1. c.) of the groups with the so-called stamen fascicles (e.g. Dilleniaceae, Crossosomataceae, Ochnaceae, Cochlospermaceae, Bixaceae, and two genera of Guttiferae, Symphonia and Vismia). His work shed light on the anatomical structures and complexities of androecia in angiosperms, and later on was used as the basis for his famous "telome concept" 12,14 .

His interpretation was based on the fact that the stamen fascicle trace observed in these plants is fundamentally identical with the vascular supply of the rachis in a primitive branch system, the ultimate of which was terminated by sporangia, such as is known to have existed in ancient and now extinct plants. Wilson ${ }^{6,12,13)}$ further advanced the hypothesis on the same evidence that a plant with a dichotomously branched plant body terminated with sporangia could be considered a primitive type of angiosperm. He thus considered as a hypothetical primitive stamen one in which a relatively long shank, or axis (an arm or limb of a dichotomy), was terminated by a system of dichotomous branches, each ultimate branchlet bearing a single sporangium. By reduction of the two most remote dichotomizing branches, with the resultant fusion of the sporangial pairs, it is possible to derive an anther with two synangia, each composed of two sporangia.

This was the condition postulated by Wilson ${ }^{6,12,13)}$ which generally prevails throughout the angiosperms. In short, the fascicle was interpreted as a primitive form of the stamen, a branching system of fertile telomes, reduced and compacted. Its vascular supply was explained as inherited from some ancient fern-like ancestors bearing no laminae (cf. Melville ${ }^{15,16)}$, Wilson ${ }^{13)}$, Zimmermann ${ }^{17,18)}$ ).

On the other hand, androecia quite different from those seen in the members of the Moronoboideae discussed here as well as in other angiosperm families were reported by Canright ${ }^{19)}$ from his studies of the Magnoliaceae and by Mosley ${ }^{20)}$ for the Nymphaeaceae. As a result of these and other observations, a different picture of the evolutionary history of the stamens in angiosperms has been postulated (cf. Canright ${ }^{19)}$, Eames ${ }^{12}$, Mosle ${ }^{201}$ ), namely, the primitive stamen was laminar, with two pairs of sporangia borne adaxially or abaxially, and from this simple stamen has developed a slender, complex organ with marginal paired sporangia. The most pro- 
minent part of the reorganization in the anther postulated by them (1. c.) is the change in the relative position of the sporangia. Progressive change in the position of the sporangium from adaxial to abaxial is considered as a feature of progressive specialization in the anther. Canright ${ }^{19)}$ and Mosley $^{20)}$ have shown in the Magnoliaceae and in the Nymphaeaceae that this change has apparently occurred quite independently in a number of different angiosperm families. As a probable process of development it was presumed that the sporangia, remaining in pairs, migrated laterally, so that they came to lie, obliquely lateral, with latero-introrse dehiscence, then lateral, with latrorse dehiscence, and as a final position, halfway around the anther, abaxial, with extrorse dehiscence. If this is the case, then this change, which is essentially a down-rolling of the entire sporophyll, must have been accompanied by an inversion of the entire vascular system. Mosley ${ }^{20)}$ interpreted the vascular supply in Nelumbo nucifera as a complex with five filament strands twisting and reorienting in their course, indicating differential growth development.

However, the nature of stamen fascicles has been the subject of much dispute up to the present time with little agreement. Recently, Eames ${ }^{21}$ gave a review of this controversial issue, and suggested that the fasciculate arrangement of the stamens may have arisen at least twice in the evolutionary history of the angiosperms, in the Dilleniales and in the woody Ranales. He did not, however, place much emphasis on the fasciculate arrangement of stamens but supported the view that the fascicle is merely an aggregation of simple stamens (Eames ${ }^{21)}$, p. 97). Melville ${ }^{15,16)}$ recently presented a more thorough and comprehensive review of the evolutionary history of androecia in angiosperms, but a complete review of his work is beyond the scope of this paper. For further details the reader is to be referred to his articles (1. c.). The present author would like, however, to discuss further some of the controversial points.

A critical examination of the vascular system of androecia in four genera of the Guttiferae-Moronoboideae (including Symphonia) has shown that there is a special type of stamen vascular system in genera other than Symphonia as described by Wilson ${ }^{6}$. This vascular system is very similar to that found in the Dilleniales but quite distinct from that seen in the Ranalian and other angiosperm families (cf. Canright ${ }^{19}$, Mosley $^{20)}$, Melville ${ }^{15,16)}$ ). In fact, at the present stage it is rather difficult to give a comprehensive account concerning their probable evolutionary development, although Melville (1.c.) made a schematic presentation of the possible historical sequence in development.

The vascular system illustrated in this paper is the one called "stamen fascicle trace" by Wilson ${ }^{6)}$, the vascular supply to stamens arising at the result of the separation of a single bundle which diverges directly from the receptacular stele (cf. Fig. $2-\mathrm{A} \sim \mathrm{H})$ but where simple orientation and inversion of the entire vascular system, as demonstrated by Mosley in Nelumbo, could hardly be regarded as possible (cf. Mosley ${ }^{201}$ ). This unique vascular supply to the stamens consists of a mass of bundles, called "siphonostele" by Wilson, at which level each stamen or petal-stamen fascicle trace branches off from the receptacular stele (Figs. 2-A $\sim \mathrm{H} ; 3-\mathrm{E} \sim \mathrm{G}$ ). In Montrouziera and Moronobea, horseshoe-shaped bundles are also formed at the same level. A specific type of bundle is rarely formed at the level where each stamen trace is given off, the type called " amphicribral" by Wilson. A good example of this is Moronobea ptaritepuiana subsp. neblinae (Fig. 5-A C). In general in the species of Montrouziera, the bundle at this level consists of xylem radiating from a center, the xylem in turn entirely enveloped by phloem. A representative of this type is shown in Figs. 2-F 
and $\mathrm{G}$ and $3-\mathrm{A}$ and $\mathrm{B}$.

A special attention should again be called to the genus Symphonia. It is interesting to note that material, called Symphonia globulifera by Wilson ${ }^{6}$, bears stamen fascicles with three stamens of four thecae each, and a reduction from four stamens to three was presumed by him on the basis of anatomical structure. As shown in Fig. 1-D, material examined in this study bears stamen fascicles with four stamens, thus proving the occurrence of both types in this species. In fact, a very similar condition is also found in Moronobea ptaritepuiana s. lat. (cf. Fig. 1-E), and it is considered to be an example of parallel development in genera with close affinities.

As was pointed out in the author's previous work ${ }^{5)}$, the four genera of the Moronoboideae here under study reveal on closer examination a similarity of the vascular system in the androecia as well, suggesting close phylogenetic relationship. The basic pattern of the formation of the stamen fascicle supply is essentially identical in all plants examined. Series of species in the genera exhibit a trend from the clustering of numerous free stamens to form multistamen fascicles to the further fusion of the fascicles and reduction of numbers of stamens per fascicle (cf. Fig. 1). Also, connation of various degrees, indicating an obvious series of evolutionary specialization, can be observed (cf. Figs. 1 and $4-\mathrm{A} \sim \mathrm{D}$ ). Evidently, the genus Symphonia represents the ultimate stage in this type of specialization. The petalstamen fascicle trace or stamen fascicle trace is fundamentally similar to the branch gap, and this fact, as was speculated by Wilson ${ }^{6,12,13)}$, suggests that the vascular system of the fascicle may have been derived from a primitive branch system through many transitionary forms, most of which are, though, untraceable at present. However, too much emphasis should not be placed on this anatomical feature alone. More complete explanations must await comparative anatomical studies of the vascular system of androecia and other floral as well as vegetative organs of all members of the guttiferous genera, including those of the Moronoboideae, and of course those of other angiosperm families as well.

\section{Summary}

1. A study is made of the development of the vascular supply for the floral parts of four genera of the Guttiferae-Moronoboideae, Moronobea, Montronziera, Symphonia, and Thysanostemon. Special reference is made to the androecium; all of these genera have characteristic fasciculate androecia.

2. It was found that in all plants examined siphonosteles are formed at the level from which the petal-stamen fascicle trace or stamen fascicle trace diverges. These steles arise directly from the receptacular stele, either independently or fused with the vascular supply to the petals. The five dissected siphonosteles formed branch off to form a vascular supply for each stamen after separation of the petal supply. The arrangement of the vascular supply for each stamen differs from genus to genus. In Montrouziera and Thysanostemon U-shaped bundles are formed, with the xylem entirely centrifugal. However, in Moronobea the bundles formed at the same level are distributed quite irregularly. In the genus Symphonia, two rows of irregularly placed bundles supplying each stamen were seen.

3. The siphonosteles seen at the level where fascicle traces formed, and the amphicribral bundles seen in the stamen supply of Moronobea are among the most unusual types of vascular system found in angiosperm androecia.

4. There is a close phylogenetic affinity in the anatomical structure of the four 
genera studied. Fusion of the fascicles and reduction of the number of stamens per fascicle occurs. The genus Symphonia apparently represents the ultimate stage of this specialization.

Grateful acknowledgment is extended to Prof. Roger Gauthier of the Institut Botanique de l'Université de Montréal, Montréal, Canada, with whose helpful suggestions and warm encouragement I was able to carry out the present study. All viewpoints presented in the present paper, however, are strictly my own responsibility. Thanks are also due to Dr. Bassett Maguire of the New York Botanical Garden for kindly supplying fixed materials of the Moronoboideae from South America and for giving me an opportunity to study this interesting group.

\section{References}

1) Engler, A., In Engler, A., and Prantl, K., Die natürlichen Pflanzenfamilien, III Teil, 6 Abteilung, Leipzig, 254 (1895). 2) Hutchinson, J., The Families of Flowering Plants. Vol. I. Dicotyledons, 2nd ed., Oxford, 510 (1959). 3) Maguire, B., Mem. New York Bot. Gard. 10: 123 (1963). 4) Perrier, H., In Humbert, 136 Famille Guttifères. Flore de Madagascar et des Comores, 1 (1951). 5) Kawano, S., Mem. New York Bot. Gard. (in press). 6) Wilson, C. L., Amer. Jour. Bot. 24: 686 (1937). $\quad$ 7) Arber, A., Ann. Bot. 27: 491 (1913). 8) —, Biol. Rev. 12: 157 (1937). 9) Saunders, E. R., New Phytol. 35: 47 (1936). 10) —, Ann. Bot. 50: 247 (1936). 11) Woodson, R. E., Ann. Bot. 50: 759 (1936). 12) Wilson, C. L., Amer. Jour. Bot. 29: 759 (1942). 13) —, Bot. Rev. 19: 417 (1953). 14)—, Aner. Jour. Bot. 37: 431 (1950). 15) Melville, R., Nature 188: 14 (1960). 16) -_, Kew Bulletin, 17 (1): 1 (1963). 17) Zimmermann, W., Die Phylogenie der Pflanzen, Stuttgart, 452 (1930). 18) —-, ibid. Revised edition, 777 (1959). 19) Canright, J. E., Amer. Jour. Bot. 39: 484 (1952). 20) Mosley, M. F. Jr., Phytomorph. 8: 1 (1958). 21) Eames, A. J., Morphology of the Angiosperms 518. (McGraw Hill, New York, 1961).

\section{摘要 \\ 河野昭一：オトギリソウ科亜科 Moronoboideae 雄性花の解剖学的研究}

Moronoboideae は中南米, アフリカ, マダガスカル, ニュー・カレドニアの熱带に局所的分布域をもつ 小さな7 属よりなるオトギリソウ科 (Guttiferae) (広義) の一亜科である。この亜科に属する植物はいずれ も向軸性で $0.8-3 \mathrm{~cm}$ に達する細長い線型の葯室をもち, 葯隔の柔組織の非常に発達した束生雄性花をつけ ることで特徵づけられる。この雄性花の非常に特異な形態からしても，他のオトギリソウ科植物の形態的 特徴を考える時, Moronoboideae に属する植物を広義の Guttiferae に一括して入れておくのは問題であ $ろ^{3,5)}$. 本研究では Moronoboideae 7 属中の 4 属に属する 6 種 Montrouziera sphaeroidea, M. cauliflora, Moronobea riparia, M. ptaritepuiana ssp. neblinae, Thysanostemon pakaraimae, Symphonia globulifera の雄性花の解剖学的特徵をしらべた。これらの 4 属に属する植物はいずれも花托にて花弁, 雄 性花へ維管束が分離, 移行の際, 中心柱から直接にいわゆる枝吵と非常に似た型をとり，5個の外篩管状 中心柱を形成する。これらから花弁への維管束が分離した後でも, 基本的に同じ管状中心柱状を示し, さ らにそれぞれの雄ずいいの維管束群を分離する。その数は Montrouziera sphaeroidea では 7, M. cauliflora で 11, Moronobea riparia で 4, M. ptaritepuiana ssp. neblinae で 3 なな 4, Thysanostemon pakaraimae で 4 または 5, Symphonia globulifera で 3 または 4 とそれぞれの種の雄ずいの数によって 一定している，絇隔の柔組織を走る維管束の排列は基本的にはすべて類似しているが，種によってはめい りょらな相違を示す. Montrouziera, Thysanostemon では花弁への維管束が分離した後でも管状に排列 した構造を保ち，葯隔の先端部に移行するにしたがい，ゆるく散開する，Moronobea は上記のものの変型 とみなされ不規則な型の外管包囲維管束状を示し, 葯隔の先端部に移行すると $10 \sim 12$ 個の小さな不規則に 排列した管束系となる.Symphonia 属はこれら 4 属中では最も特殊化したものとみなされ，雄性花の横 
断面に見られるとおり， 3 または 4 個の雄ずいが完全に癒合した形態を示す。また維隔部も完全に癒合し筒 状となり，横断面でみると環状である。雄ずいへの維管束は花弁への管束が分離した後，やや不規則な分 裂をくり返し，先端部に進むに従い二列に並立した型となる。

ここに記載された 4 属の植物の束性雄性花の維管束系はWilson によって報告された Dillenales に属す る植物のものと基本的に同じ構造を示し, Mosley, Canright (cf. Eames) らにより観察された Ranales の Magnolia, Nymphaea, Nelumbo なぞの雄性花の維管束系とは対照的な違いを示す. 雄性花の起源は

Wilson らがいらように葯室をもった原始的な二又分枝より由来するものであるか, またら Eames の主張するよらに葉類より由来するものであるのか，それともまた，現在未だ化石が発見されていないよ らな形態をもつものを通じていろいろな型を示すものが放散的に分化してきたものであるのか一いずれ にせよ今後, 化石拈よび現存する植物の比較解剖学的研究を待だねばなるまい（東京大学理学部植物学教 室) 